\title{
The Beats' Identification with the Marginalized Groups as a Means of Decentralization
}

\author{
Ehsan Emami Neyshaburi \\ Department of English Language-University of Neyshabur-Iran \\ ehsanemamin@live.com
}

DOI: http://doi.org/10.36892/ijlls.v2i3.369

\begin{tabular}{|c|c|}
\hline $\begin{array}{l}\text { Received: } \\
\text { 10/08/2020 }\end{array}$ & $\begin{array}{c}\text { Abstract } \\
\text { Because the cold war had already started and atomic annihilation was }\end{array}$ \\
\hline $\begin{array}{l}\text { Accepted: } \\
\text { 16/09/2020 }\end{array}$ & $\begin{array}{l}\text { impending, America was panicked into bringing about homogeneity and } \\
\text { centralization. The government thought that diminution of heterogeneity and } \\
\text { propagation of the privileged discourses could guarantee the country against }\end{array}$ \\
\hline $\begin{array}{l}\text { Keywords: } \\
\text { Beats; } \\
\text { Decentralization; } \\
\text { Marginalized } \\
\text { Groups; } \\
\text { Heterogeneity; } \\
\text { Homogeneity }\end{array}$ & $\begin{array}{l}\text { the threat. Opposing this, the Beats strived to bring about difference and } \\
\text { heterogeneity to guarantee their society against tastelessness and lack of } \\
\text { individuality, as the inevitable corollaries of this policy. They identified } \\
\text { themselves with the marginalized groups because they knew that being on the } \\
\text { periphery of American society, these groups had not been corrupted by } \\
\text { capitalism. Their purity, difference from the rest, and natural condition helped } \\
\text { the Beats fulfill their purpose. Some critics believe they were insensitive to the } \\
\text { plight of those groups and only misused them and some others say that the Beats } \\
\text { had an ambivalent attitude towards them and the positive and negative aspects } \\
\text { of their relation should be considered. This paper is going to support the second } \\
\text { view. }\end{array}$ \\
\hline
\end{tabular}

\section{INTRODUCTION}

As World War II ended, the cold war began almost immediately. The Soviet Union established communist puppet governments across central and Eastern Europe. Communism was recognized as a main political force and the Communist Party of the United States had already increased its membership. For the same reason, the American government panicked and started imposing a kind of cultural and political homogeneity. As a result, in the 1950s McCarren Internal Security Act and the notorious McCarthyism came into existence. The first one required the government to investigate the people who were thought to have engaged in subversive activities which could lead to the establishment of a totalitarian fascist or communist dictatorship. Members of such groups could not become citizens or sometimes were not allowed to enter or leave America. An emergency law required the President to exercise his authority in order to arrest people or suspects whom the government thought might have committed acts of espionage or sabotage. McCarthyism derives its name from the campaign that Senator Joseph McCarthy launched against communism and its increasing spread in America. When the United States was fighting communism outside American soil in Korea, Senator McCarthy was actively hunting communists inside. McCarthyism accused people of treason or subversion without proper evidence. Citizens in all walks of American life including artists and playwrights were under suspicion and investigation and the government tried to find out whether they were communists or even sympathized with communists. Opposing these homogenizing tendencies which could turn the country mundane and square, the Beats strived to bring about heterogeneity and difference. Although 
an unusual activity at that time, they mixed with and befriended African Americans publicly and admired their language and music. In fact, this mixture was a technique of the Beats to decentralize the white society and neutralize its homogeneity. Some critics believe they were insensitive to the plight of those groups and only misused them and some others say that the Beats had an ambivalent attitude towards them and the positive and negative aspects of their relation should be considered. This paper emphasizes and espouses those views that point out to the Beats' ambivalence and tries to refer to both positive and negative aspects of their relation with the marginalized groups as well.

\section{LITERATURE REVIEW}

Decentralization is an important theme in the Beats' literature and life. To decentralize American society, the Beats had invented a few ways that one of them was identification with the marginalized groups. No work has dealt with this issue independently but the following sources were basically inspiring. Bloom's Modern Critical Interpretations Jack Kerouac's ON THE ROAD has compiled ten essays looking at the novel from different angles. Vopat, for instance, reevaluates the novel and considers issues such as the characters' relation with Mexicans and Negroes. Skerl's Reconstructing the Beats is one of the most important books written on the Beats. It covers multiple issues such as Beat culture, heterogeneity, Beat-Mexican intersections, individual resistance, travelling, jazz, improvisation, Buddhism, and visions. Holladay's what's Your Road, Man? is all about Kerouac's On the Road. Chandarlapaty's The Beat Generation and Counterculture consists of three parts which two deal with Burroughs, and Kerouac. These two were not collaborators but there is a great deal of common ground between them meaning that they created groundbreaking modern American perspectives and studied the Orient and the other or nonwhite cultures. In William Burroughs and the Secret of Fascination Harris tries to show the secret history of Burroughs' writing. He believes that looking at the visible part of Burroughs' writing will not suffice for revealing the truth about his writing. In Understanding Jack Kerouac Theado enunciates that On the Road is basically about the pursuit of the American dream in postwar America and the characters' protest against materialism and conformity.

\section{DISCUSSION}

The Beats were dead set against Jameson who had said: "Capitalism destroys genuine human relationships, but also for the first time liberates humankind from village idiocy and the tyranny and intolerance of tribal life" (Mulhern, 1992, p. 176). Instead of liberation, according to them, capitalism brought about thraldom in a modern way and it was the same modernity that had led to the invention of the atomic bomb. So, this modern civilization was irrational and they believed that the exclusion of marginalized groups from modernity had guaranteed their immunity from irrationality and other perils of civilization. A full guarantee came as the Beats knew that African Americans were 'completely' maladjusted and it was impossible for them to adjust. Riesman (1989) distinguishes between the terms adjusted, autonomous, and anomic. The adjusted are those who reflect the norms of their society or class with the least distortion. Anomic that Riesman borrowed from Durkheim means ungoverned and ruleless and almost is synonymous with maladjusted. The autonomous are those who are capable of conforming to the norms of the society but they are free to choose whether to conform or not and this is a capability that the anomics lack because they have no choice (p. 242). According to this theory, the Beats should be considered as autonomous because they chose to be nonconformists but African Americans were anomics because they could not adjust themselves to society completely and society could not assimilate them, too. 
Belgrad (1998) enunciates that the Beat writers got fed up with the academic situation because they thought the academy had fallen prey to the cold war discourses. In response to this situation, the Beats regarded marginal status as an asset not as a failing and valued the survival strategies of the dispossessed in their writings. Belgrad (1998) suggests, "these dispossessed seemed to share an ethos that did not focus on achievement" (p. 197). Therefore, apart from African Americans, the Beats were absorbed by figures like Huncke the addict and Cassady the joyrider who represented "the true inhabitants of America's social margins" (p. 197). Belgrad (1998) quotes Ginsberg who asserted "the simple political and social awareness that centralization is a failure, is a loss, a loser. And that decentralized energy forms, and decentralized cultural forms are ... the richest" (p. 197). These decentralized cultural forms, that is, marginalized groups, had survived modernity's cultural downfall.

Additionally, opposing Jameson' idea, the Beats were inspired by Spengler's The Decline of the West. Burroughs lent this book to Kerouac who derived the word fellahin from it. Fellaheen, as Spengler (1926) spells it, represents marginal people on the periphery of civilization or at the edge of a culture which is already in spiritual decline: "we find everywhere in these Civilizations that the provincial cities at an early stage, and the giant cities in turn at the end of the evolution, stand empty, harbouring in their stone masses a small population of fellaheen who shelter in them as the men of the Stone Age sheltered in caves and pile dwellings" (p. 107). It is not accidental then, that Spengler uses the expression "Faustian man" (pp. 13, 68, 75, 78, and 85) which refers to a legendary figure who sells his soul to the devil in return for scientific knowledge and progress. By the same token, the Beats objected to America's unbridled technological progress which of course, had led to the invention of atomic bombs. These fellahin people lived beyond the scope of American capitalist consumer culture and therefore, the Beats accepted, were more authentic and real; they actually admired and emulated this kind of life. Of course, the fellahin people of America were not responsible for its lack of spirituality that Sal notices in On the Road: "I felt it was ridiculous: in my first shot at the West I was seeing to what absurd devices it had fallen to keep its proud tradition" (Kerouac, 1959, p. 21) and Holton submits that this "is the collapse of history into depthless postmodern parody" (Bloom, 2004, p. 83). Reacting against this postmodern tendency, Holton continues, Kerouac located the 'real' in the fellahin because they never experienced this loss or identified with the narratives of white dominance that prescribed its own versions of reality (Bloom, 2004, p. 84). Kerouac in On the Road describes the fellahin this way:

we would finally learn ourselves among the Fellahin Indians of the world, the essential strain of the basic primitive, wailing humanity that stretches in a belt around the equatorial belly of the world from Malaya (the long fingernail of China) to India the great subcontinent to Arabia to Morocco to the selfsame deserts and jungles of Mexico and over the waves to Polynesia to mystic Siam ... (Kerouac, 1959, p. 162).

This mixture brought about difference, heterogeneity, and decentralization. According to Bloom (2004), in this way the Beats were able to "ridicule the authorities, debunk the myths, expose the hypocrisies, and, thus, delegitimate the culture of domination" (p. 79). Holton, using Bourdieu's ideas, mentions another reason for the Beats' identification with marginalized groups. Bourdieu believes that those artists and intellectuals who do not find bourgeois acceptance usually tend to feel an affinity with marginalized groups because their position is homologous (Bloom, 2004, p.90). Perhaps this idea could not be set in the Beat context. The Beats had difficulty getting their works published (especially Kerouac), as an 
example, and lack of acceptance had become an obsession with them but it was unlikely that identification with the marginalized groups could help out. However, in the following sections, we examine some of the Beats' works to practically discover their positive and negative attitudes towards the marginalized groups.

\section{THE BEATS WERE AMBIVALENT TOWARDS THE MARGINALIZED GROUPS}

Giamo reports that D. H. Lawrence in his Studies in Classic American Literature quotes this line by Walt Whitman: "Stay in the dark limbs of negroes. Stay in the belly of the prostitute." Giamo, then, concludes that this quote affirms Whitman's democratic location and his sympathy with the oppressed (Bloom, 2004, p. 205). Because Whitman was a main mentor of the Beats, it is essential to pay attention to the fact that he, as opposed to the above-mentioned quotation, had an ambivalent attitude towards African Americans and the Beats are very much after the fashion of him and that ambivalence is a common feature of many men of letters:

Whitman felt a kind of aversion to blacks, according to Asselineau, who adds that the poet, who could "scarcely hide his disgust for Negroes," went as far as to reproach them with the color of their skins. Whitman believed blacks "quite incapable" of governing themselves, and shared the opinion with Carlyle that "God had created the blacks to act as servants to the whites." He thought that the black race lacked the drive to self-rule, and that somehow its natural place is a subservient one. Whitman did not believe in the amalgamation of whites and blacks. Neither did he wish it to happen. Indeed, as Kuebrich remarks, he hoped that blacks would be one day sent back to Africa or at least somewhere outside the United States. While working as a nurse in the hospitals in Washington during the war, Whitman said that, in comparison with the ongoing slaughter, he "did not care for the niggers," ... Somehow unsurprisingly, when describing some positive quality in the black soldiers who were fighting the war, Whitman made an aesthetic observation: "[W]e cannot find fault with the appearance of this crowd - negroes though they may be. They are manly enough [ . . ]. Many of them real handsome young fellows." (Herrero Brasas, 2009, pp. 67-8).

Charles Aldridge remembers that although always opposed to slavery, Whitman thought that the matter had been taken as too all-important (Herrero Brasas, 2009, p. 174). Lott contends that Kerouac provided a Whitmanesque tribute to the beauty in all Americans, Negro or Indian (Skerl, 2015, p. 177) that given the above-mentioned quote we cannot be sure except that according to the Beats it was heterogeneity and difference that brought about beauty to which marginalized groups, because of their difference with the rest, contributed substantially but the fact is that this difference included their way of life and their dire situation in society in comparison with the privileged. It is not accidental that many critics argue that the Beats were not political and did not strive to change the situation of marginalized groups for the better because they worried that perhaps change for the better might lead to the dilution of difference. Another reason was Buddhism in which the Beats were very interested. In Buddhism suffering was a truth of the world and by no means it could be wiped out because "Generally, what we think will be an answer turns out to be the cause of more suffering, so again we look for a solution-the cycle is endless" (Hope, 2000, pp. 30-32). The Beats, as alienated people, believed that they suffered themselves; so, it was 'natural' for the marginalized groups to suffer too and this was the main reason of their identification with them: "he had found people like himself" (Kerouac, 1959, p. 162), the 
narrator refers to Dean in On the Road when he is in Mexico. That is to say, "Breaking down the Self's inundation with "mainstream" modern consciousness meant ... supplanting Western institutional dominance of the mind with the urgency of historicized naturalism (Chandarlapaty, 2009, p. 79). Or "The Orient is natural, pure, sensibly liberated; the Occident is grey, decayed, and insidious (p. 87). However, like his mentor, Kerouac had an ambivalent attitude towards the Jews. Most of the time he insulted them and sometimes he came to his senses and was disgusted at his behaviour towards the poor Jews (Sterritt, 2004, p. 15).

Holton argues truly that in On the Road there is, on the one hand, a foregrounding of the conventions and limitations of racial identity in order to challenge the existing social order and on the other hand, there is a misrecognition of these limitations and conventions. As a result, there seems to be a profound paradox entailed in Kerouac's search for freedom. In fact, Holton continues, the Beats aspired to join the excluded others on the margins but not on the barricades (Bloon 2004, pp. 78-9). Chandarlapaty (2009) submits that both Kerouac and Burroughs simply ignored the "discursive agency of the Other"; they were orientalists "with no true interest in dramatizing the economic and social plight of the Other" (p. 167); that is why perhaps that they did not have a sense of responsibility in their relationship with the Mexicans and Negroes. Additionally, Burroughs not only identifies himself against "visible backwardness and harmfulness of non-Western cultures" but also denies "traditional Orient communities any truly modern agency" (Chandarlapaty, 2009, p. 72). So, according to Chandarlapaty, the white (like the Beats) internalized black, Mexican, and Chinese consciousnesses to only lead them away from the civilization which was characteristically white, rational, capitalist, and technological (p. 104). It should remind us of Foucault who enunciates that the marginalized groups can define themselves only through their struggle with power. Conversely, the mainstream members of society, that is, those who are not marginalized, are less constrained. Although the power network defines them initially, they enjoy a significant range of further self-definition. As a matter of fact, within society, they have niches that, according to Foucault, provide them room for self-formation (Gutting, 2005, pp. 103-104). And this is in fact, the difference between the white Beats and other marginalized groups that we cannot deny. Holton complains that Kerouac on the one hand, absorbs the reader's attention to the lives of the marginalized groups and on the other, he fails to recognize and penetrate the stereotypical frames of the marginalized other and in this way limits the understanding of those lives. He argues, too, that Kerouac provides no point of view from the margins. As a matter of fact, Kerouac was blinded by his romanticizing of the other and his maturity was blinded, too, by his fear of change. Eventually, Holton refers to positive and negative aspects of Kerouac's career by saying that he displays an amalgamation of insight into the urgent need to break down the hegemonic structures of ethnicity and race and blindness to the lived and real experiences of the marginalized people (Bloom, 2004, pp. 88-9).

\section{THE BEATS RESPECTED THE MARGINALIZED GROUPS}

Some critics very much admire the Beats for the way they idolized African Americans or Mexicans and strengthened their position in American society. Miles counts Burroughs as a practitioner of the sixties civil right movement especially because of his expressions of outrage at the treatment of the black in Naked Lunch (Sterritt, 2004, p. 16). Some quotations from Naked Lunch prove this: "nigger killing sheriffs look us over and check the car papers" (Burroughs, 1959, p.14) or "let's go see the mad nigger .... They had that nigger chained to the bed, and he was balling like a cow (p. 87). African Americans and Mexicans, as a matter 
of fact, provided positive role models for the Beats who were alienated whites. Sal, in On the Road, for example, wants to use them as his models:

wishing I were a Negro, feeling that the best the white world had offered was not enough ecstasy for me, not enough life, joy, kicks, darkness, music, not enough night ... I wished I were a Denver Mexican, or even a poor overworked Jap, anything but what I was so drearily, a "white man" disillusioned (Kerouac, 1959, p. 105).

Barbara Ehrenreich (1983) praises the Beats because "They were probably the first group of white Americans to believe that "black is beautiful," for blacks were, perforce, permanent outsiders, who countered their rejection from the white world by creating their own language and art" (p. 56). Chandarlapaty (2009) points out that Kerouac's novels present Negroes in charge of an intellectual revolution; expose white-Negro separateness, hence their contribution to Civil Rights movements; humanize white comprehension of Negro consciousness; and recognize black society and culture as American (p. 7). Ginsberg, too, appreciates African Americans and strives to divulge the dire situation in which they live in America. In Howl for example, he refers to the districts that the Negroes live in: "I saw the best minds of my generation destroyed by madness, starving hysterical naked, /dragging themselves through the negro streets at dawn looking for an angry fix" (Schumacher, 2015, p. 21). Or in Kaddish: "Uncle Sam in Newark, plotting deathly perfumes in the Negro district?" (p. 33).

In comparison with the happy Negroes of America, as the following quote from $O n$ the Road shows, Sal is very sad and dissatisfied:

A gang of colored women came by, and one of the young ones detached herself from motherlike elders and came to me fast--"Hello Joe!"--and suddenly saw it wasn't Joe, and ran back, blushing. I wished I were Joe. I was only myself, Sal Paradise, sad, strolling in this violet dark, this unbearably sweet night, wishing I could exchange worlds with the happy, true-hearted, ecstatic Negroes of America (Kerouac, 1959, p. 105).

This positive and easy identification with the Negroes is because, as Ginsberg commented, Kerouac like his African American fellows, felt himself an outsider: "the descendant of French Canadian immigrants ... marked by a different cultural background ... never completely assimilated into American life. From ... childhood, he was well acquainted with the feeling of being an outsider" (Myrsiades, 2002, p. 79). Wilson believes that Kerouac's search for the truth required him to not only 'dig' or study the lives of the dispossessed but also attempt to become them at least for a time (Myrsiades, 2002, p. 79). In general, the Beats "felt like blacks caught in a square world that wasn't enough for [them]" (Tytell, 1976, p. 22). Above all, in On the Road, the Negroes are generally more sophisticated than the white: "Although Gene was white there was something of the wise and tired old Negro in him" (Kerouac, 1959, p.19). According to Sal, the Negroes enjoy a high-quality "joyous life that knows nothing of disappointment and "white sorrows" and all that" (p. 106). In other words, white sorrows are the inevitable result of "white ambitions" (p. 105) that the Negroes' life is devoid of. Holton enumerates three characteristics of the Negroes' life that the Beats extolled: "ridicule of upper-class pretensions", "moral permissiveness", and "simplicity and happiness" (Bloom, 2004, p. 81). Spirituality is still a characteristic of the Negroes' life and Sal notices it: "There was an old Negro couple in the field with us. They picked cotton with the same God-blessed patience the grandfathers had practiced in 
antebellum Alabama" (Kerouac, 1959, p. 57). It is not accidental then, that just like Spengler, Emerson, one of the Beats' mentors, comparing "the well-clad, reading, writing, thinking American, with a watch, a pencil and a bill of exchange in his pocket" with "the naked New Zealander, whose property is a club, a spear, a mat" comes to the conclusion that the latter is healthier because the former "has lost his aboriginal strength" (Atkinson, 1950, pp. 166-67).

Swartz (2001) illustrates that Kerouac in his works rejects the Eurocentric bias towards African Americans; in On the Road both Sal and Dean borrow their language and music; especially Dean, just like the Negroes, is poor and disenfranchised and exhibits all the sexual behaviours that have been stereotypically attributed to the black (pp. 88-9) through "differential racialization" which refers to "the ways the dominant society racializes different minority groups at different times, in response to shifting needs" (Delgado, 2001, p. 8). So, Dean becomes a 'white Negro' as Bloom (2003) quotes Norman Mailer's definition of it in his famous article with the same title: "The hipster had absorbed the existentialist synapses of the Negro, and for practical purposes could be considered a white Negro" (p. 79). Bloom (2004) also quotes Malcolm X who had commented "A few of the white men around Harlem ... acted more Negro than the Negroes" (p. 78). Kesey, too, a Beat himself, "claimed to have "outniggered" blacks" (Echols, 2002, p. 33). Of course this internalization of the other, Chandarlapaty (2009) argues, led the Beats away from the modern technological civilization that they were dead set against; a civilization that lacked spiritual resonance and selfconstitution (104). Consequently, both the Negroes and the Beats become American outcasts and another characteristic that they have in common is that they live in the now or at the moment:

Warren Tallman writes that outcasts in America in the 1940s, such as Negroes, had been forced to accept the futility of integration into society as a whole. Instead, they inhabit a "social purgatory" ... one way these outcasts cope is by giving up their egos and falling back not upon the mercy of society but into the moment, an existence entirely in the "now." To survive there, they must learn to "swing": "To swing is to enter into full alliance with the moment ... (Theado, 2000, p. 67).

Sal and Dean live in the now and in fact, one of the meanings of "It" (Kerouac, pp. 75, 120) about which Dean speaks multiple times in On the Road is the same. Once they are in a car which belongs to a fag and on their way to Kansas. There are two other passengers, too. Dean makes an interesting comparison between themselves and these two passengers:

we know what IT is and we know TIME ... "Now you just dig them in front. They have worries, they're counting the miles, they're thinking about where to sleep tonight, how much money for gas, the weather, how they'll get there ... But they need to worry and betray time with urgencies false and otherwise, purely anxious and whiny, their souls really won't be at peace unless they can latch on to an established and proven worry and having once found it they assume facial expressions to fit and go with it, which is, you see, unhappiness, and all the time it all flies by them and they know it and that too worries them no end (Kerouac, 1959, p. 121).

As a matter of fact, Kerouac brilliantly shows that despite surface differences between these outsiders, deep human affinities endure and this is one value of this novel (Theado, 2000, p. 68). Chandarlapaty (2009) defends Kerouac by saying that he illustrated white-black 
ethnographic and spiritual oneness and introduced a modern minority culture into the modern imagination of white reading audiences (p. 106). Or it was Kerouac "who popularized a wide range of non-Western works of literature, cultures, and philosophies, making them sensible and readable for English-medium White Americans, and relating their philosophical meanings to a country largely indifferent to the Other's place in history" ( $p$. 111), and in Chandarlapaty's view, many black and white authors painted black farmers as victims and oppressed figures but "Sal's portrait painted Black tenancy as resonant and historically functional rather than anxious and trampled upon" (p. 115).

The Beats multiple times travelled to Mexico; a country in which corporate culture and bureaucracy were not firmly established, yet. So, there they could easily resist capitalism and its corporate institutions. Like the Negroes, Mexicans were another group of the fellahin people who lived on the periphery of civilization and had preserved their purity, and spiritual destruction had not affected them. Kerouac was so interested in Mexican culture that in a letter he wrote that he felt like an Indian exile; he was neither European nor American (Theado, 2000, p. 66). While in Mexico in On the Road, Dean "had found people like himself" (Kerouac, 1959, p. 162). Although French-Canadian, he went even further and believed Indian Blood circulated in his veins and therefore, felt deep sympathy for Indians (Tytell 168). It stands to reason that Kerouac (1959) in On the Road is not disrespectful to Indians:

we would finally learn ourselves among the Fellahin Indians of the world, the essential strain of the basic primitive, wailing humanity ... These people were unmistakably Indians and were not at all like the Pedros and Panchos of silly civilized American lore ... they were not fools, they were not clowns; they were great, grave Indians and they were the source of mankind and the fathers of it. The waves are Chinese, but the earth is an Indian thing. As essential as rocks in the desert are they in the desert of "history" (p. 162).

Putting Mexicans on a pedestal, he criticizes Americans as "self-important moneybag" (p. 162); people so corrupted by civilization. Also in On the Road, on an LA bus, Sal meets a Mexican girl, Terry. Her story is that "She had a husband and child. The husband beat her, so she left him" (Kerouac, 1959, p. 50); they become friends and he "promised her beautiful love" (p. 50); immediately they start a relationship but after a while like many other occasions, Sal begins to 'get the bug' and at last leaves her. As opposed to what some critics like Vopat (Bloom, 2004, pp. 4-5) and Ligairi (Holladay, 2009, p. 150) think, Sal cannot completely ignore Terry's life. When they go to the place in which Terry and her family live, Sal notices "her sister's house in the sliverous Mexican shacks" (Kerouac, 1959, p. 53) and "what a wild place it is, with chickenshacks barely big enough to house a jukebox" (p. 53) or "It was a four-room shack; I couldn't imagine how the whole family managed to live in there ... There were no screens" (p. 59). He is even ready to encounter Terry's husband: "There was talk that Terry's husband was back in Sabinal and out for me; I was ready for him" (p. 58). Sal tries to please and keep her happy: "I rushed back to Terry, all glee. On the way a grape truck went over a bump in the road and threw off great bunches of grapes on the hot tar. I picked them up and took them home. Terry was glad" (p. 57) or: "I bought cans of cooked spaghetti and ... prayed to God for a better break in life and a better chance to do something for the little people I love ... It was Terry who brought my soul back" (p. 57-8). Sal, of course, is not completely callous and tries to expose the racism that existed in American society but to him, difference or heterogeneity is a more important issue and Terry's natural life and suffering make the difference. The Beats' reaction to a society that trampled on their individuality and ignored their natural aspirations and forced them to 
conform, was to be different and resist conformity and mix with marginalized groups and minorities like African-Americans or Mexicans who were like themselves different and resided on the periphery of American society.

Above all, Sal identifies himself with the Mexicans: "They thought I was a Mexican, of course; and in a way I am" (Kerouac, 1959, p. 58). Or "Sighing like an old Negro cotton picker, I reclined on the bed and smoked a cigarette" (p. 58). Dean realizes another difference between America and Mexico: "notice the old lady or the old man is always somewhere around ...They're never alone. Nobody's ever alone in this country" (p. 162). When they go to a brothel, Sal again encounters human suffering and feels guilty. He sees a sixteen-year-old coloured whore who is very sorrowful and detached. At one point her mother comes and has a brief and mournful conversation with her daughter and as a result, Sal is too ashamed to try for this girl that he really wants. He cannot take his eyes off her and thinks that of all the girls in there, she needs the money most and maybe her mother had come to get money from her for her little brothers and sisters.

In Burroughs's Cities of the Red Night, after Captain Mission explores the Madagascar coast, the colony is called "Libertatia" and is "placed under Articles drawn up by Captain Mission. The Articles state, among other things:

all decisions with regard to the colony to be submitted to vote by the colonists; the abolition of the death penalty; and freedom to follow any religious beliefs or practices without sanction or molestation ... Any man would have the right to settle in any area of his choosing. The land would belong to those who used it. No white-man boss, no Pukka Sahib, no Patróns, no colonists (Burroughs, 1987, pp. 3-4).

This society presents "a wide variety of physical types: blondes, redheads, Indian, Chinese, Negro, Portuguese, Spanish, Malay, Japanese, and some mixed blood" (p. 54) and in this way becomes a brilliant heterogeneous society.

\section{THE BEATS DISRESPECTED THE MARGINALIZED GROUPS}

Joan Haverty claims that while Kerouac was writing Terry's episode, he impregnated her with their daughter. She believed that Kerouac's passion was inspired by his feeling of superiority over an abject woman of colour; he could not feel this superiority over his white wife (Bloom, 2004, p. 159). Ligairi contends that even cotton-picking, as backbreaking labour, does not elicit Sal's sympathy for those who do not have the opportunity to quit it, as he does (Holladay, 2009, p. 148). Whenever Sal faces a financial problem he returns to his aunt or in an episode he takes an easy hundred dollars from a girlfriend; that is why Bennett points out that the episode 'borrowing easy money from a rich girl he knows' is not compatible at all with the episode 'wishing he were a Negro' (Myrsiades, 2002, p. 8). Swartz (2001) insists that in On the Road Sal and Dean borrow the language, drugs, music, and even despair of repressed people in order to redescribe their own positions (p. 88). The same thing is almost reiterated by Morrison: "black characters are used as a foil in the construction of white identity, while simultaneously being deprived of their own interiority and constitution of selfhood" (Burrows, 2004, p. 100). Additionally, Ligairi enunciates that Sal may share physical space with repressed people but he actually skirts around the periphery of their cultural worlds (Holladay, 2009, p. 148). Richardson argues that Sal's way of dreaming about the Mexicans and African Americans is eminently a white way of dreaming about them. As a matter of fact, he reduces them to poverty only to flatter them with suggestions that their lives are charmed and idyllic and free from white anxiety, responsibility, and 
inhibitions. In brief, with suggestions that they are really natural (Bloom, 2004, p. 215). This kind of behaviour, of course, maintains the status quo and in On the Road, leads into getting "only three dollars per hundred pounds of picked cotton" (Kerouac, 1959, p. 57). Reading about "happy, true-hearted, ecstatic Negroes of America" (Kerouac, 1959, p. 105), Podhoretz, the Beats' worst enemy, in an article condemns Kerouac and lampoons this quotation by saying that to the Negroes it will be news to learn that they are so ecstatic and happy (Swartz, 2001, p. 87). Richardson also criticizes Kerouac for depicting blacks freer than whites and their suffering as if it were a kind of gift. Kerouac mounts evidence to the contrary, Richardson says, and his heroism is the odd heroism of a con-artist (Bloom, 2004, p. 220). Corso once accused Kerouac of racism in On the Road but he did not accept it giving a clever answer: " "poetic statements' in artistic works did not commit him to them in his personal life" (Mckee, 2004, p. 6). Polsky (1967), too, believes that the Beats did not contribute to the life and situation of the Negro in America:

They accept the Negro only for his "Negro-ness" (as the bringer of marihuana and jazz, etc.) and thus practice an inverted form of "keeping the nigger in his place." ... While beats should be given credit for the best of conscious intentions, but it is disheartening how often their actions confirm that old Negro proverb, "Whenever you see a white man with a colored man, the white man wants something from the colored man." To see that Negroes living in the interracial beat world are still "invisible men" means to become sharply aware of something that white beats characteristically dodge: no modern urban Negro-raised as he is on white movies, white comic books, white television — can avoid internalizing white ideals ... Contrary to what may white beats believe, there is hardly a Negro alive who in his heart of hearts doesn't want to be white ... (pp. 181-82).

Just like Kerouac, Burroughs was sick of America and loved Mexico. The difficulties of having sex, taking drugs, and police harassment caused him to move to Mexico in 1949. In Mexico it was easier for him to find out drugs, guns and above all, boys to have sex with. Contrary to Mexico, America had lost its "glorious Frontier heritage of minding one's own business" (Harris, 1993, p. 61). Burroughs adds: "If they do go to bed with another male, and they all will for money, they seem to enjoy it. Homosexuality is simply a human potential ... and nothing human is foreign or shocking to a South American" (p. 176). When Burroughs started Junkie he had become a Mexican citizen: "What a relief to be rid of the U.S. for good and all, and to be in this fine free country" (p. 65)! In Queer Lee appears to be a complete racist; his imperial identity and its superiority are crystal clear. When a Mexican passerby insults Allerton and Lee, Lee reacts like this: "A Mexican said, "Cabrones," as he walked by. Lee called after him, "Chinga tu madre," then added in English, "Here I come to your little jerkwater country and spend my good American dollars and what happens? Insulted inna public street." (Burroughs, 1985, p. 53). Or his behaviour towards a Mexican blond boy: "A blond Mexican boy went by pushing a cart. "Jesus Christ!" Lee said, his mouth dropping open. "One of them blond-headed Mexicans! 'Tain't as if it was being queer, Allerton. After all, they's only Mexicans. Let's have a drink" (p. 77). Harris (2003) comments that Lee "seems to relish the oppression and objectification of others in a psychological maneuver that implicates a national pathology" (p. 104). Lee's racist reaction to a hotel neighbour who wants him to be quiet is very notorious and high-profile:

The inside wall to Lee's room stopped about three feet from the ceiling to allow for ventilating the next room, which was an inside room with no windows. The occupant of the next room said something in Spanish to the effect Lee should be quiet. "Ah, shut up," said Lee, leaping to his feet. "I'll nail a blanket over that 
slot! I'll cut off your fucking air! You only breathe with my permission. You're the occupant of an inside room, a room without windows. So remember your place and shut your poverty-stricken mouth" (p. 107)!

Because Lee's efforts to draw Allerton into a homosexual relationship with him proves to be abortive, Harris (1999) believes this "sadistic aggression towards racial others seems to be an act of hysterical compensation for the impotence in his sexual relationship" (p. 259). Harris (2003) also mentions Lee's identification with Caesar in Queer, quotes Olson's famous remark that "the American has the Roman feeling about the world" (p. 106). This quotation from Queer, too, shows Lee's fascistic attitude towards the South Americans: "What they need here is a security department, to keep the underdog under" (Burroughs, 1985, p. 106). Sal, too, shows his imperial identity in On the Road; while in America, he wishes to have a different identity but in Mexico, his American identity is strengthened: "the strangeness of Americans and Mexicans blasting together on the desert and, more than that, the strangeness of seeing in close proximity the faces and pores of skins and calluses of fingers and general abashed cheekbones of another world" (Kerouac, 1959, p. 164). Just because Lee "felt killing hate for the stupid, ordinary, disapproving people who kept him from doing what he wanted to do" (Burroughs, 1985, p. 97), he grows a dreamlike utopia that "involved a river. He lived on the river and ran things to please himself. He grew his own weed and poppies and cocaine, and he had a young native boy for an all-purpose servant" (p. 97). Harris (2003) calls this master-servant relationship "colonial ... and seed of totalitarianism" (p. 110). In fact, Lee wants to guarantee total freedom for himself at the expense of the other's freedom.

Burroughs (1959) has the same attitude towards Arabs in Naked Lunch: "Did I ever tell you about the time Mary and I pay two Arab kids sixty cents to watch them screw each other" (p. 33)?, "What you gonna do when the oil goes dry? /Gonna sit right there and watch those Arabs die" (p. 80). Moreover, in a letter to Ginsberg, Burroughs reveals his attitude directly: "What's all this old Moslem culture shit? ... They sit around smoking cut weed and playing some silly card game ... They are just a gabby, gossipy, simple-minded, lazy crew of citizens" (Chandarlapaty, 2009, p. 87). This, of course immediately should remind us of Orientalism and the Westerner's prejudices against Orientals: "Orientals or Arabs ... shown to be gullible, "devoid of energy and initiative," much given to "fulsome flattery," intrigue, cunning, and unkindness to animals ... Orientals are inveterate liars ... "lethargic and suspicious," and in everything oppose the clarity, directness, and nobility of the AngloSaxon race" (Said, 1977, p. 38).

\section{CONCLUSION}

Although the Beats in so many respects were very different from each other, because of some affinities, they shared some sort of group identity. One of the most important characteristics that they all shared was their interest in primitivism. In other words, they respect the land and its indigenous people as we see in On the Road when they travel to Mexico and respect Indians or the fellahin people of the area. As a matter of fact, the Beats believed that those people had not been affected or infected by corrupt Western civilization and its irrational technocracy. Therefore, they emphasized the naturalness and beauty of their lives. Of course, they transcended this and tried to identify themselves with the fellahin people of these countries striving to reach a complete understanding of their rituals and their archaic thought. The Beats' identification with the marginalized groups is very famous. Notwithstanding this identification, some critics who are themselves sometimes ambivalent, as mentioned above, accuse the Beats of being inattentive or insensitive to their 
plight and using their works, strive to prove it. From the point of view of social psychology of course, it is not that easy to prove it this way. Accordingly, when people identify with another, it does not merely mean that they wish to be like the other but that they unconsciously imagine that they 'are' the other and if the second one or the other benefits, the subject benefits too and if the second one suffers, the subject also suffers. Prejudice against the other and racism, occur unconsciously and as we saw both Burroughs and Kerouac attributed them to their characters rather than themselves and the same thing makes it difficult to judge them guilty of racism. Above all, when a social system considers some prejudices as valid and therefore does not think of them as prejudices, naturally, when they occur, they are often not spotted; when dehumanization has become habitual, we socially do not notice and regard it as normal. Separation and alienation of the mainstream members of American society from its marginalized groups had become valid and habitual. The Beats at least tried to inverse the situation and absorb people's attention to their prejudices and to do this, they should have resisted their own prejudices first; as Wilson believes that Kerouac "battled between his need for embracing openness and his need for writing through the fracturing of his prejudices" (Myrsiades, 2002, p. 77). Denial of this separation and those who denied it were both taboos and that was why the Beats oftentimes were oppressed and regarded as dangerous by society and were driven out as outcasts. In other words, they were thought as impure or dirty people who did not "fit the conceptual scheme" of their society and as we know "nothing is dirty in itself, but only relative to a system of ordering and evaluation' (Auestad, 2015, p. 63). As many Negroes have desired to pass themselves off as whites, the Beats at their own time aspired to exchange worlds with the Negroes or Mexicans. In fact, identification with the marginalized groups made rebellion easier for the Beats. Decentralization of society and neutralization of its homogeneity were greater purposes for them to fulfil via this identification.

\section{REFERENCES}

Atkinson, Brooks. (1950). Ed. The Complete Essays and Other Writings of Ralph Waldo Emerson. New York: Random House.

Auestad, Lene. (2015). Respect, Plurality, and Prejudice. London: Karnac.

Belgrad, Daniel. (1998). The Culture of Spontaneity. Chicago: The University of Chicago Press.

Bloom, Harold. (2004). Ed. Jack Kerouac's On the Road. Philadelphia: Chelsea House.

—. Ed. (2003). Norman Mailer. Philadelphia: Chelsea House.

Burroughs, William S. (1987). Cities of the red Night. London: John Calder Publishers. . (1959). Naked Lunch. New York: Grow press. (1985). Queer. New York: Viking.

Burrows, Victoria. (2004). Whiteness and Trauma. New York: Palgrave Macmillan. Chandarlapaty, Raj. (2009). The Beat Generation and Counterculture. New York: Peter Lang. 
Delgado, Richard, and Jean Stefancic. (2001). Critical Race Theory. New York: New York University Press.

Echols, Alice. (2002). Shaky Ground The'60s and Its Aftershocks. New York: Columbia University Press.

Ehrenreich, Barbara. (1983). The Hearts of Men. New York: Doubleday.

Gutting, Gary. (2005). Foucault: A Very Short Introduction. Oxford: Oxford University Press.

Harris, Oliver. (1999) Can You See a Virus? The Queer Cold War of William Burroughs. Journal of American Studies 33.2: 243-266.

Harris, Oliver. (1993) .Ed. The Letters of William S. Burroughs, 1945-59. New York: Viking.

Harris, Oliver. (2003). William Burroughs and the Secret of Fascination. Carbondale: Southern Illinois University Press.

Herrero Brasas, Juan A (2010). Walt Whitman's Mystical Ethics of Comradeship. Albany: Suny Press.

Holladay, Hilary, and Robert Holton. (2009). Ed. What's Your Road, Man? Illinois: Southern Illinois University.

Hope, Jane, and Borin Van Loon. (2000). Introducing Buddha. Cambridge: Icon Books.

Kerouac, Jack. (1959). On the Road. New York: The Viking Press.

Mckee, Jenn. (2004). Jack Kerouac. Philadelphia: Chelsea House Publishers.

Mulhern, Francis. (1992). Ed. Contemporary Marxist Literary Criticism. London: Longman. Myrsiades, Kostas. (2002). Ed. The Beat Generation Critical Essays. New York: Peter Lang.

Polsky, Ned. (1967). Hustlers, Beats, and Others. Chicago: Aldine Publishing Company.

Riesman, David, Nathan Glazer, and Reuel Denney. (1989). The Lonely Crowd. New Haven: Yale University Press.

Said, Edward. (1977). Orientalism. London: Penguin.

Schumacher, Michael. (2015). Ed. The Essential Ginsberg. New York: Harper Perennial.

Skerl, Jennie. (2004). Ed. Reconstructing the Beats. New York: Palgrave.

Spengler, Oswald. (1926). The Decline of the West. New York: Alfred. A. Knopf.

Sterritt, David. (2004). Screening the Beats. Carbondale: Southern Illinois University Press.

Swartz, Omar. (2001). The view from On the Road. Illinois: Southern Illinois University press. 
Theado, Matt. (2000). Understanding Jack Kerouac. Columbia: University of South Carolina Press.

Tytell, John. (1976). Naked Angels. New York: McGraw Hill Book Company. 